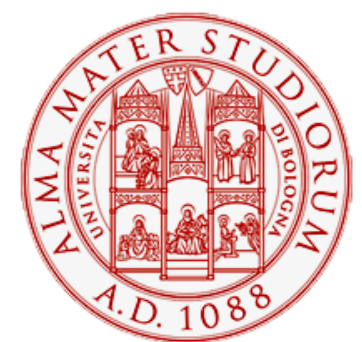

Alma Mater Studiorum - Università di Bologna DEPARTMENT OF ECONOMICS

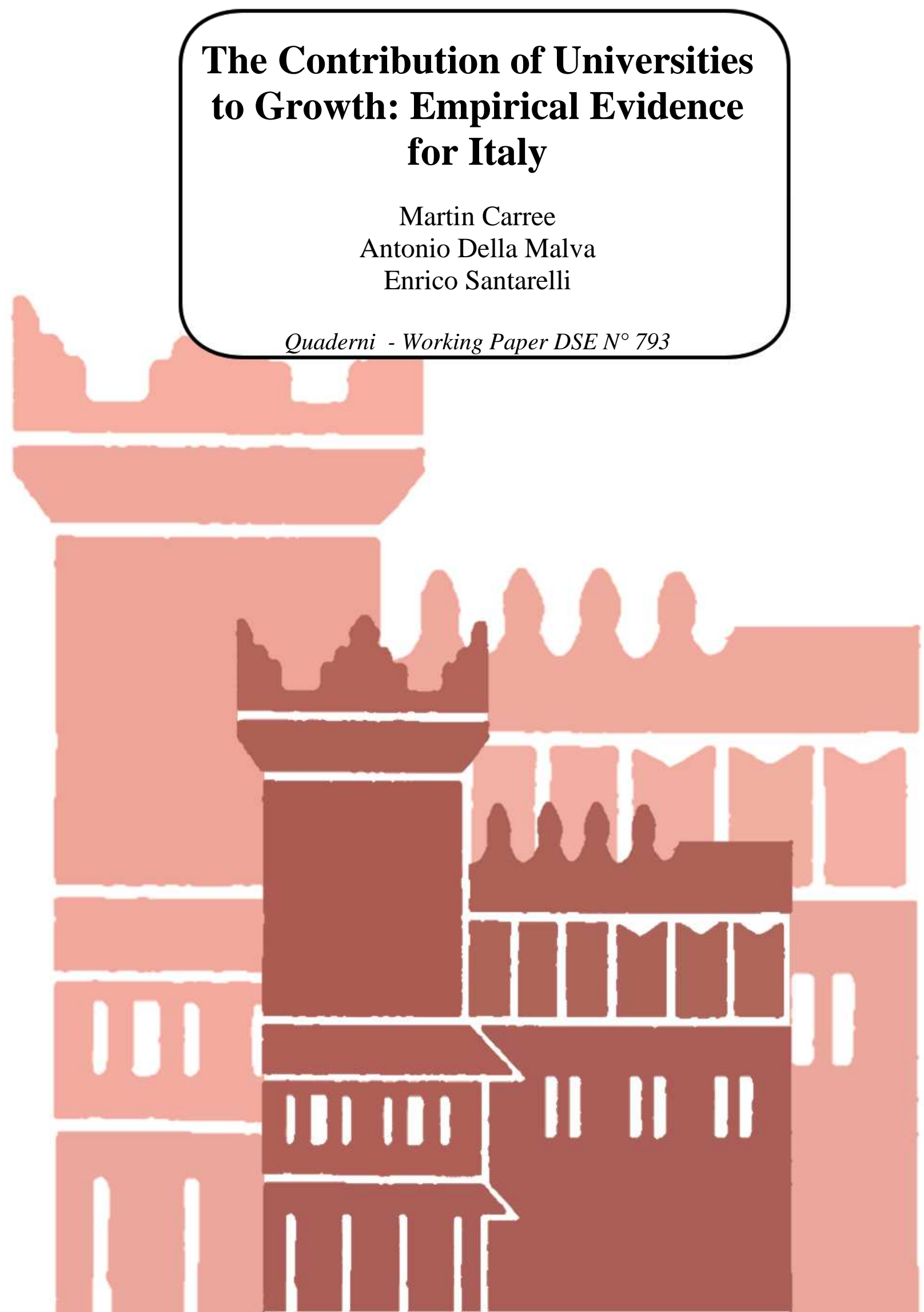




\title{
The Contribution of Universities to Growth: Empirical Evidence for Italy*
}

\author{
by \\ Martin Carree \\ Maastricht University, Faculty of Economics and Business Administration, P.O. Box 616, 6200 MD Maastricht, \\ the Netherlands, tel: +31 43 3884981, E-mail: $\underline{\text { m.carree@ maastrichtuniversity.nl }}$ \\ Antonio Della Malva \\ Katholieke Universiteit Leuven, Faculty of Economic and Applied Economic Sciences, Naamsestraat, 69, 3000 \\ Leuven, Belgium, tel: +32 16326 730, E-mail: antonio.dellamalva@econ.kuleuven.be \\ Enrico Santarelli \\ University of Bologna, Department of Economics, Piazza Scaravilli, 2, I-40126 Bologna, Italy, \\ tel: +39 51 2098487, E-mail: enrico.santarelli@unibo.it
}

Version: October 21, 2011

\begin{abstract}
New entrepreneurial ventures may represent a viable and effective mechanism to transform academic knowledge into regional economic growth. We test this notion for the Italian provinces between 2001 and 2006. We evaluate three outputs of academic activities: teaching, research and Intellectual Property Rights (IPR) activities management. New ventures may be able to transform the mentioned outputs into improved economic performance. The findings show that the effects of academic outputs on provincial economic growth (all sectors) are appreciable when they are associated with sustained entrepreneurial activities in the province. It suggests that academic inquiry may provide new ventures with valuable commercial opportunities overseen by established companies.
\end{abstract}

Keywords: University research $\cdot$ Regional growth $\cdot$ Entrepreneurship $\cdot$ Italian provinces

JEL Classifications: $\mathrm{I} 23 \cdot \mathrm{O} 18 \cdot \mathrm{O} 34 \cdot \mathrm{R} 11$

\footnotetext{
* Previous versions of this paper have been presented at the $6^{\text {th }}$ Annual Conference of the EPIP (European Policy for Intellectual Property) Association (Brussels, 8-9 September 2011), and the 2011 Annual Meeting of the Technology Transfer Society (Augsburg, 21-23 September 2011), where it received the Best Paper Award. We thank David Audretsch, Erik Lehmann and Roberta Piergiovanni for helpful suggestions. E. Santarelli acknowledges financial support from University of Bologna (RFO2009 and RFO2010). A. Della Malva acknowledges financial support from European Commission under the program COST-STRIKE (COST-STSMIS0604-5332).
} 


\section{Introduction}

How does knowledge spur economic growth? The theories of endogenous growth use the informational characteristics of knowledge as introduced by Arrow (1962) to explain endogenous growth trajectories (Romer, 1986; Lucas, 1988). According to these theories, it is the generation of knowledge that spurs growth and such knowledge is partially appropriable as it spills over into the hands of third parties that in turn use it to generate new knowledge and useful ideas.

Although endogenous growth theories have predicted general patterns of growth, they fail in explaining the several "paradoxes" that are currently crowding decision-makers' agendas. In fact, some scholars have contended that it is not investment in knowledge per se that spurs growth and thus competitiveness; rather, the critical facet of the economic relevance of knowledge is the commercialization of the results that knowledge produces (Acs et al., 2009; Audretsch and Keilbach, 2008; Braunerhjelm et al., 2010). These authors posit the existence of a "knowledge filter" between investment in new knowledge and its economic exploitation. Such a filter results from the inherent peculiarities of knowledge, as opposed to information itself. Knowledge generating activities produce uncertain economic results that are associated with high degrees of asymmetries between inventors and potential exploiters. High uncertainty and high asymmetries result in high transaction costs among economic agents (Audretsch, 2007).

These characteristics become even more evident when knowledge is generated in academic laboratories. A strand of literature in the sociology and economics of science fields stresses that the incentive system in place within the academic community would rarely lead scientists to produce findings of immediate industrial application (Dasgupta and David, 1994; Merton, 1973; Stephan, 1996). The recent involvement of universities in technological development has in fact shown that whenever academic findings display potential technological applications, they are at an early stage of development and tend to serve a variety of industrial purposes (Colyvas et al., 2002; Jensen and Thursby, 2001; Piergiovanni and Santarelli, 2001).

In such a context, entrepreneurship is seen as the main mechanism that ensures both the flow of radical technological change into the economy and the economic exploitation of the knowledge (Audtretsch, 1995; Klepper and Sleeper, 2005; Schumpeter, 1934). Schumpeter (1934) was the first to identify a mechanism, that he named "creative 
destruction", through which new and independent ventures bear the main responsibilities in the process of economic growth through innovation. The main rationale underlying this argument is that large players would oversee promising ventures because of being locked into existing products and production processes (Christensen, 1997; Hill and Rothearmel, 2003; Spulber, 2010).

In this study we test the hypothesis that entrepreneurship represents an effective mechanism to transform academic knowledge into economic growth. Specifically, we evaluate three outputs of academic activities: teaching, research, and Intellectual Property Rights (IPR) activities management, along with the importance of new ventures to transform the mentioned outputs into improved economic performance. The analysis is carried out for the Italian provinces between 2001 and 2006.

The study is organized as follows: Section 2 gives an overview of the existing literature on the importance of academic activities for economic growth and the relevance of new ventures in appropriating and exploiting economically academic outputs; Section 3 introduces the estimation strategy and describes the variables used in this work; Section 4 presents and discusses the estimation results; and Section 5 summarizes the main results in the paper.

\section{Universities, Entry and Growth}

\subsection{Universities and Economic Growth}

The role of modern higher education institutions (universities henceforth) in the economic performance of firms, sectors, regions and countries can be approached from different perspectives.

Modern universities evolved from the medieval model in which they served as repositories of knowledge and wisdom, with the preservation and transfer of existing knowledge as their main goal. They were organized like guilds, where masters taught small groups of students. Although in the late $18^{\text {th }}$ century their mission was extended to educate civil servants to fill the administrative ranks of the newly formed European states, it was not

until the mid- $19^{\text {th }}$ century that universities embraced a second mandate of institutionalizing the pursuit of scientific research through rational inquiry and experimentation. Universities then became an important source of academically trained graduates and scientific knowledge to meet the needs of industrial sectors emerging from the second industrial revolution. The 
two activities of teaching and performing basic research have been complemented by the more recent entrepreneurial activities of universities. Universities are no longer only suppliers of knowledge-intensive outputs such as students and research papers as they also proactively engage in research collaborations with private parties through licensing, sponsored research and new venture creations (Etzkowitz and Leyersdorf, 1998). Whereas the first transition in universities saw the emergence of new organizational forms such as research laboratories, the latter transition is resulting in the creation of technology transfer offices, university-industry research centers and incubators. ${ }^{1}$

Education is the oldest contribution of academic activities to economic growth. It is usually associated with the formation of higher levels of human capital, viz. the development and refinement of specific individual knowledge and capabilities. The increase in human capital enables individuals to perform higher value-added tasks more efficiently and quickly, which translates in higher productivity of labour and capital (Becker, 1964; Barro, 1991; Lucas, 1988). Moreover, students may act as important channels through which knowledge is transmitted to the industry. For instance, several studies (including Nelson and Wright, 1992; Murnmann, 2003) show that students represent a critical conduit of the latest techniques and theoretical know-how from academic laboratories to the corporate ones in the chemical, mining and pharmaceutical industries. Also in the case of biotechnology, firm performance has been driven by the supply of highly skilled graduates in life sciences, as opposed to direct Research and Development (R\&D) expenditures, which has eased both the adoption of new process technologies and the commercialization of new products (Patel et al., 2006). Finally, and more remarkable for the purpose of the present study, the share of adult population with tertiary education has been shown by Sterlacchini (2008) to be the most effective factor enhancing the growth of GDP per capita recorded during the period 1995-2002 in the regions belonging to twelve EU countries.

Universities are also the most prominent producers of fundamental knowledge, which has been argued to be one of the main drivers of economic growth. The theories of endogenous growth built upon the informational characteristics of knowledge as introduced by Arrow (1962) suggest that the generation of knowledge would enhance the production of

\footnotetext{
$1 \quad$ University involvement in a region is not by definition a guarantee for success. University initiatives may for example tend to follow in stead of cause vibrant high-technology clusters. Breznitz (2011) describes how constant one-sided changes in technology transfer policy and organization have had a negative effect on Cambridge University's ability to commercialize technology.
} 
more efficient processes and products and hence spur growth (Romer, 1986, 1990). However, scholars in the economics of technical change field have long focused their attention only on R\&D activities performed in corporate laboratories to explain technology-driven growth. Indeed, knowledge produced in academic laboratories is of a somewhat different nature than corporate R\&D. Academic scientists pursue research goals that are informed by their personal curiosity and by the reward system in the academic community which is based on peer recognition rather than on monetary compensations (Merton, 1973). Hence it is not surprising that academic findings rarely have immediate industrial applications. Rather, they expand the theoretical pool of knowledge upon which technical advances of commercial value can be built (Fleming and Sorenson, 2004).

Adams (1990) shows that between 1949 and 1983 it took around 20 years for scientific advancements to be absorbed and exploited by industries and ultimately lead to productivity growth. The time lag of academic knowledge to result in economic gains has shortened in the last three decades. Three stylized facts highlight this convergence between science and technology: a) the higher productivity of corporate R\&D led by the increasing pervasiveness of scientific approaches in corporate $R \& D$ as opposed to trial-and-error methods (Arora and Gambardella, 1994); b) the rise of new science-based sectors in which the innovation process depends mostly on developments arising from academic R\&D, i.e. ICT and biotechnology, as key sectors in industrialized countries (Orsenigo, 2003; Zucker et al, 1998a; Pisano, 2006); and c) the increasing involvement of universities in commercialization activities such as sponsored research, technology licensing and equity positions in academic spinoffs (Shane, 2004; Henderson et al., 1998; Fini et al., 2009). Yet, the interest in the role of academic R\&D as driver of growth drew largely on the examples of ICT and biotech in California and Massachusetts, which host some of the most prolific scientific universities worldwide (Saxenian, 1994).

The link between the quality of research outputs and the likelihood of generating technologically useful knowledge has received empirical support from a burgeoning body of literature in the field of technology transfer. Highly productive scientists engage in technological developments: they manage contractual agreements with industrial partners, engage in consulting relationships and fund companies (Agarwal and Henderson, 2002; Azoulay et al., 2009; Zucker et al., 1998b). Despite academic quality, the extent to which academia supports commercialization activities plays a role. Faculty in universities that openly oppose any involvement in commercialization activities might exert little if any 
influence on the transfer of academic knowledge (Owen-Smith and Powell, 2001). Feldman and Desroches (2003) provide a detailed case of how the reluctance to allow commercial interests to influence faculty research agendas at the John Hopkins University, despite its scientific eminence, slowed down the emergence of a high-technology cluster in the Baltimore area. Hayter (2011) argues that academic entrepreneurs usually have little interest in growth but are motivated more by success in terms of technology development, public service and peer effects.

\subsection{Entry, Knowledge and (Regional) Growth}

From an economic standpoint, the rate of new entry and entrepreneurial dynamics of markets have gained attention and importance in the last couple of decades ${ }^{2}$. Steady flows of new businesses add new capacities to the market and thereby represent a key source of economic growth. The dynamic consequences of high birth rates are not univocal: large numbers of new comers leave the market immediately after start-up but are also associated with the exit of older incumbents. Besides the direct effects of entry on growth, indirect effects from the supply-side can take place. High entry rates, by contesting established markets, force incumbents to make efficient use of resources (Baumol et al., 1988), limit the effectiveness of anticompetitive behaviours and foster incumbents' innovativeness (Geroski and Jaquemin, 1984). Moreover, new entrants have been found to be a major mechanism of new markets creation through the commercialization of radical innovations (Audretsch, 1995; Prusa and Schmitz, 1991). Accordingly, new ventures seem to be fitter than incumbents in exploiting knowledge which is characterized by high uncertainty and high information asymmetries.

Acs et al. (2009) propose a theoretical framework to account for the ability of new entrants to exploit radical knowledge developed elsewhere (i.e. large companies and research institutes) and transform it into economic growth. The authors posit the existence of a knowledge filter, which hampers the commercial exploitation of the full set of knowledge developed in research laboratories. The authors analyze the context of knowledge from corporate laboratories finding that, given the existence of sunk investments such as dedicated human capital, physical capital and vertical relationships, incumbents often neglect new opportunities as they are unwilling to face the risk of implementing new products or processes. Moreover, companies can rarely rely upon alternative mechanisms to compensate for the underexploited knowledge, such as markets for technologies. Transaction costs are

$2 \quad$ See Thurik and Carree (2003) for a review of the determinants of the renewed economic interest in entrepreneurship. 
inherently high when the technology to be traded is characterized by uncertainty about economic results and information asymmetries between the parties involved in the transaction (Arora and Gambardella, 2010). Yet, entrepreneurs, often former employees of incumbent firms, are expected to have lower opportunity costs and higher expectations about returns from commercialization of new knowledge than incumbent firms themselves ${ }^{3}$. Hence they are more prone to start up new companies to commercialize the new knowledge that the latter have created. Examples of empirical regional studies showing that entrepreneurial activity is important for knowledge flows and exploitation include Audretsch and Lehmann (2005) and Mueller (2006, 2007), each using German data.

Academic knowledge shares most of the economic features of radical knowledge from corporate laboratories in that its applications are far from evident. According to the existing literature in the economics and management of technology transfer field, technologies created by academics are mainly at an early stage of development, general in purpose, characterized by high uncertainty about their actual applications and demand further development efforts from the buyers and inventors to be commercialized (Colyvas et al., 2002; Jensen and Thursby, 2001; Jensen et al., 2003). Although incumbents might possess the necessary capacity to absorb external knowledge (Cohen and Levinthal, 1990), idiosyncratic investments can restrict the range of acquirable knowledge. Hence, the same mechanisms that bring incumbents to oversee radical opportunities from corporate laboratories are expected to lead to underexploited academic knowledge. Evidence on the critical role of new ventures in exploiting radical academic technologies is supported by the early evolution of the electronics and biotechnology industries (Bania et al., 1993; Zucker et al. 1998a).

\subsection{The Italian case}

Regions may constitute a very useful unit of analysis for investigating the impact of the presence of university outputs and the rate of new entry of firms. The first can be seen as a measure for the 'academic climate' and the latter as a measure for the 'entrepreneurial climate'. We are interested whether one of the two or both simultaneously are important to promote economic growth. In this study we focus on Italian provinces, a sub-regional level of government introduced by Article 114 of the Italian constitution with statutory, regulatory and administrative competences, but not entitled to approve statutes or laws. There are in total 77 universities in 49 provinces in Italy. That means that slightly less than half of the Italian

\footnotetext{
3 The laser industry, the disk drive industry and the tire industry experienced this kind of evolution (Klepper and Sleeper, 2005; Buensdorf and Klepper, 2009; Agarwal et al., 2004).
} 
provinces have a university. The choice of this territorial unit of analysis is mostly driven by the availability of the data. Yet, it can provide useful perspectives for assessing the role played by entrepreneurship, new knowledge and other spatially bounded characteristics in enhancing local growth.

Two arguments to defend our decision to focus on administrative provinces can be provided. First, by specifically addressing the issue of spatial autocorrelation, we are able to explain to what extent the neighbouring provinces might have an effect on growth in the focal province, therefore providing an indirect measure of the reasonableness of the use of this administrative spatial cluster as unit of analysis. Second, the majority of Italian provinces include the capital city of the corresponding administrative region and these capitals are relatively large cities with the surrounding towns closely connected to that city for economic, social, cultural, and spatial reasons. As recently shown in a study performed for the European Commission (Europe Innova, 2010), the largest concentrations of entrepreneurial activities with favorable perspectives of growth in Europe are major urban areas, which attract the most talented workers.

\section{Estimation Strategy: Methods, Variables and Data}

\subsection{Methods}

In order to test the hypothesis that newly established ventures are critical in the conversion of academic knowledge into economic growth, we propose the following models that we estimate for 99 Italian provinces (NUTS3), indexed by $i$, between 2001 and 2006 (index $t$ ):

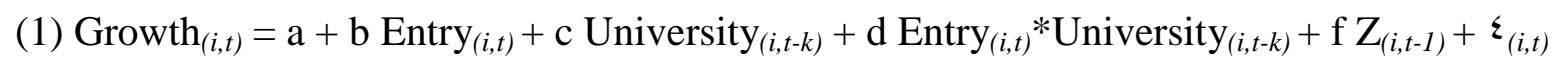

We model growth in the province as a function of business entry in the same year and of the set of academic outputs described in Section 2. The measures of business entry and academic outputs are interacted to capture the contribution to growth of new ventures via the exploitation of the academic knowledge-base in the province. The set of variables $\mathrm{Z}$ controls

\footnotetext{
$4 \quad$ Due to a substantial reorganization of the provinces located in Sardinia, we have excluded the provinces located in the region. Hence, we are left with 99 provinces which represent the remaining 19 Italian regions in 2001. There are 75 universities in 47 out of 99 provinces. Note that the number or provinces has slowly but steadily increased in the last decades. The number in 2011 is already 110.
} 
for additional factors that can contribute to economic growth and will be detailed later in this section. Measures of university outputs are lagged by $k$ years. The value of $k$ varies according to the type of activity (details in section 3.2).

The treatment of units of analysis with spatial attributes presents some estimation challenges (Anselin, 1988; Glaeser and Kerr, 2009). Traditional linear estimation techniques might lead to estimation biases as they do not take into account that observations can be spatially dependent. A strand of literature in spatial econometrics has proposed two classes of models as solutions for this problem: Spatial Error Models (SEM) and Spatial Autoregressive Models (SAR). SEM models extend the equation to be estimated by decomposing the error term into one component that is spatially independent and another component that accounts for spatially dependent unobservables. SAR models consider that economic activities in nearby regions can exert positive externalities. To account for this effect, SAR models include a spatially weighted measure of the dependent variable among the regressors.

So, following Elhorst (2003), we extend the model (1) to account for spatial interdependence and additionally estimate the following two models:

(2) $\operatorname{Growth}_{(i, t)}=\mathrm{a}+\mathrm{b}$ Entry $_{(i, t)}+\mathrm{c}$ University $_{(i, t-k)}+\mathrm{d}_{\text {Entry }}^{(i, t)}{ }^{*} \operatorname{University}_{(i, t-k)}+\mathrm{fZ}_{(i, t-1)}+\mathrm{h} \mathrm{W} *$ $\zeta_{(j, t)}+v_{(i, t)}$

(3) $\operatorname{Growth}_{(i, t)}=\mathrm{a}+\mathrm{b}$ Entry $_{(i, t)}+\mathrm{c}$ University $_{(i, t-k)}+\mathrm{d}$ Entry $_{(i, t)} * \operatorname{University}_{(i, t-k)}+\mathrm{f} \mathrm{Z}_{(i, t-1)}+\mathrm{h}$

$\mathrm{W}^{*} \operatorname{Growth}_{(j, t)}+\varepsilon_{(i, t)}$

where $\mathrm{W}$ is a $99 \times 99$ weighting matrix, which is calculated as 1 , if two provinces share a border, and 0 otherwise. Model (1) can be estimated using least squares techniques, while models (2) and (3) are estimated using maximum likelihood. Italian provinces may not suffer/benefit from strong spatial interdependence, because they have a capital city that is usually the main economic engine for the province and is in the majority of cases located in the center of the territory. In addition, we incorporate provincial dummies (fixed effects) into the models (1)-(3) which may take away commonalities in the error term or dependent variable of adjacent provinces. Nevertheless, we investigate the magnitude of the possible estimation bias due to spatial interdependence either in the error term or dependent variable. 


\subsection{Variables and Data}

We employ two measures of economic growth. The first one is related to the so-called restricted industry (manufacturing, mining, and energy) in the province and is measured as the relative rate of growth of value added in the restricted industry:

(4) $\Delta \mathrm{VA} \_I S S_{(i, t)}=\left(I S S \_V A_{(i, t)}-I S S \_V A_{(i, t-1)}\right) / I S S \_V A_{(i, t-1)}$

The second variable reflects the overall economic performance of a province and is calculated as the relative rate of growth of value added per province:

(5) $\Delta \mathrm{VA}_{(i, t)}=\left(V A_{(i, t)}-V A_{(i, t-1)}\right) / V A_{(i, t-1)}$

We measure entry rate differently for the two specifications. In the model for the restricted industry, we calculate entry as the gross number of new registrations in the manufacturing sector each year ( $t$ ranging between 2001 and 2006) per 1000 employees in the restricted industry in the province:

(6) Manu_E $\mathrm{E}_{(\mathrm{i}, \mathrm{t})}=$ new registrations in Manufacturing ${ }_{(\mathrm{i}, \mathrm{t})} /\left(\mathrm{ISS} \_L a b o r_{(\mathrm{i}, \mathrm{t})} / 1000\right)$

Entry in the model for the overall economy is calculated as the gross number of new registrations in the manufacturing sector and in the service sector per 1000 employees across all sectors in the province:

(7) $\mathrm{E}_{(\mathrm{i}, \mathrm{t})}=$ new registrations in Manufacturing and Services ${ }_{(\mathrm{i}, \mathrm{t})} /\left(\right.$ Employment $\left._{(\mathrm{i}, \mathrm{t})} / 1000\right)$

The two specifications of gross rate of entry $\left(M a n u_{-} E_{(i, t)}\right.$ and $\left.E_{(i, t)}\right)$ are used to accommodate for the direct short-run impact of the entrepreneurial activities carried out in the province on economic growth. We also account for the share of new businesses in innovative industries to allow for potential growth premia stemming from high-technology initiatives, namely 
businesses driven by 'opportunity' rather than 'necessity'. The measures used are the share of high-tech manufacturing (High_Share) in the restricted industry specification and the share of high-tech manufacturing, knowledge-intensive services and technology-intensive services (Ki_Share) in the total growth specification. ${ }^{5}$ Information about entry in Italian provinces was retrieved from the database Movimprese, provided by UnionCamere, the Italian Association of Chambers of Commerce. It contains yearly new registrations and cancellations at each provincial Chamber of Commerce. Data are further organized per 2-digit NACE sector.

Three indicators of academic outputs are included in the analysis. First, we measure the educational mandate of universities (Students ${ }_{i, t-1}$ ) as the share of Science and Technology (S\&T) graduates at $t-1$ divided by the population in the province at $t-1$. We lag graduates by one year to account for the transition to the labour market. There are at least two effects of the presence of large teaching universities with respect to growth. Firstly, they signal the extent to which high-quality human capital is present in the province. Yet, large portions of students per resident population can hamper economic growth as their spending power may be limited as compared to that of workers. Moreover, we interact Students with our measures of entry $\left(M a n u_{-} E\right.$ and $E$ ) to control for the ability of new ventures to exploit the economic potential of human capital embedded in university graduates. We do not expect the latter variable to have a sizeable influence on economic growth as new ventures may prefer to hire experienced workers to benefit from their social capital. Information on the number of students was retrieved from the statistical office of the Ministry of Higher Education and Research. ${ }^{6}$ It reports the number of graduates from each university, the faculty, the location of the teaching activities and whether the students attained vocational education. We retrieved data on graduates and assigned them to the location of the faculty which issued the degree, as during the last two decades a number of academic institutions have decentralized teaching activities towards adjacent provinces with the aim of meeting the local demand for education (Piergiovanni et al., 2011).

The second measure of academic output is related to scientific research (Publications $i, t-2)$. It is constructed as the number of internationally recognized scientific productions in Science and Technology fields at $t-1$ divided by the number of graduates at $t-2$. The lags are chosen to reflect that it may take one year for scientific papers to be published. We use the

\footnotetext{
5 We follow the sectors aggregation used by EUROSTAT. Although four classifications are proposed high, medium high, medium-low and low tech - we grouped the first two in high-tech and the remaining in lowtech. 
number of graduates in Science and Technology as benchmark because personnel in universities is mostly hired according to teaching needs; hence, Publications provides an indirect measure of the intensity of the scientific activities at Italian universities. Moreover, the scientific productivity of the academic personnel may represent a crude proxy for the quality of the knowledge produced in academic laboratories. Due to data constrains, we cannot use longer lags than two years, as statistics for graduates are available only as from 1998 on. The implications for growth are not so clear. Scientific productivity has been found to be a good predictor of technological solutions as theoretical advancements might either improve existing technologies or require new ones to tackle new scientific challenges (Fleming and Sorenson, 2004; Franzoni, 2007). Yet, empirical evidence points at longer time frames than two years to appreciate the impact of scientific knowledge on productivity gains (Adams, 1990). For academic knowledge to translate in economic growth it needs to be brought to the marketplace. We hence interact Publications and market entry to control for the diffusion of scientific knowledge via new ventures. We expect new ventures to introduce solutions of greater economic impact as compared to established companies. Data about scientific production was retrieved from the "Web of Knowledge", a database administered by the Institute for Scientific Information (ISI). We report all articles with at least one author affiliated to Italian universities. Data were then aggregated at provincial level, when necessary.

Thirdly, the direct involvement of universities in technological activity is included $\left(I_{P R} s_{i, t-4}\right)$. Given the limited extent of the direct involvement by universities in IPR-related issues, it can hardly have a substantial effect on growth. However, technological activities at academic laboratories may indicate the orientation of academic research towards industrial applications and the propensity to collaborate with external partners. This can become beneficial for established companies and new ventures which may not encounter institutional frictions. As patenting is an occasional activity at universities, hence subject to high disturbances in the short run, IPRs is obtained as the annual average of the number of national patent applications from universities in the previous four years over the average number of scientific articles in the same years. This long time frame is justified by the long time lag with which patents are cited (Czarnitzki et al, 2011; Sampat et al., 2003). We interact IPRs and entry to assess the effects of entrepreneurial policies by universities towards technology development on the economic contributions of new ventures. Information about university patenting was obtained from Patjunkie, a web-based patent search engine realized by the 
Bologna University based research group IRIS ${ }^{7}$. We are aware that this measure is strongly biased downward as Italian academic professors tend to leave ownership of their inventions to companies (Lissoni et al., 2008). However, the main focus of our analysis is to account for the orientation of university policies towards commercialization.

We control for the provincial industrial structure as it can affect the growth rate of local economies and the extent to which agglomeration economies emerge. We use three measures to account for industrial composition and innovativeness of the regional (provincial) economies. Due to data constraints, as a proxy of the presence of manufacturing (ISS) in the province we use the share of the labor force in the whole restricted industry sector (source: ISTAT). Furthermore, the ability of the secondary sector to absorb and exploit knowledge ultimately depends on its current innovative performance (Cohen and Levinthal, 1990). We control for the degree of innovativeness of the industrial sector (PAT_ISS). This measure is defined as the number of national patents granted per 1000 employees in the restricted industry sector and it is lagged by one year (source: $U M B I$ ). A widespread presence of the business services sector indicates the existence of agglomeration economies due to diversification. We include for this purpose the share of workforce employed in the business services sector(Business_Services). Finally, we control for the heterogeneity of productivity and income across Italian provinces by incorporating the logarithm of the one-year lagged level of value added per capita $\left(L_{-} V A P C\right)$ and we include the one-period lagged dependent variable $\left(\Delta V A_{-} I S S_{(i, t-1)}\right.$ or $\left.\Delta V A_{(i, t-1)}\right) .^{8}$ All controls are lagged by one year.

Table 1 presents summary statistics (i.e., mean, standard deviation, minimum, and maximum) for all variables included in the empirical analysis. The correlation matrix can be found in Table 2. The dependent variables of the analysis show little correlation (0.38), and also the correlation among the explanatory variables is a source of little concern: there are very few correlations above 0.4 (Log_VAPC with Manu_E and High_Share; Manu_E and ISS; Students and Business_Services) and are moderate to low, implying little multicollinearity problems.

\footnotetext{
$7 \quad$ http://www.evpat.net/patjunkie/search.asp

$8 \quad$ The inclusion of a lagged dependent variable in a fixed effects model may give rise to biases, especially for the effect of the lagged dependent variable. However, since the dependent variable is a change and we are not interested in the coefficient for the lagged dependent variables, the biases should be minimal. See also Bun and Carree (2005).
} 
Table 1: Summary Statistics

\begin{tabular}{|c|c|c|c|c|c|}
\hline Variable & & Mean & Std. Dev. & Min & Max \\
\hline \multirow[t]{2}{*}{ d_va_indss } & overall & 0.019 & 0.048 & -0.117 & 0.182 \\
\hline & within & & 0.043 & -0.095 & 0.191 \\
\hline \multirow[t]{2}{*}{ d_va } & overall & 0.043 & 0.031 & -0.049 & 0.142 \\
\hline & within & & 0.029 & -0.035 & 0.134 \\
\hline \multirow[t]{2}{*}{ Log_VAPC(t-1) } & overall & 3.897 & 0.112 & 3.561 & 4.149 \\
\hline & within & & 0.044 & 3.751 & 3.996 \\
\hline \multirow[t]{2}{*}{ d_vaindss(t-1) } & overall & 0.023 & 0.054 & -0.117 & 0.224 \\
\hline & within & & 0.049 & -0.103 & 0.193 \\
\hline \multirow[t]{2}{*}{ d_va (t-1) } & overall & 0.047 & 0.031 & -0.049 & 0.142 \\
\hline & within & & 0.029 & -0.041 & 0.133 \\
\hline \multirow[t]{2}{*}{ Manu_E (t) } & overall & 7.135 & 3.575 & 2.564 & 26.963 \\
\hline & within & & 1.485 & 0.223 & 16.312 \\
\hline \multirow[t]{2}{*}{ High_Share(t) } & overall & 0.168 & 0.064 & 0.035 & 0.387 \\
\hline & within & & 0.027 & 0.083 & 0.269 \\
\hline \multirow[t]{2}{*}{$\mathrm{E}(\mathrm{t})$} & overall & 8.377 & 1.964 & 5.114 & 22.654 \\
\hline & within & & 0.861 & 5.068 & 12.721 \\
\hline \multirow[t]{2}{*}{ Ki_Share(t) } & overall & 0.223 & 0.065 & 0.084 & 0.595 \\
\hline & within & & 0.059 & 0.04 & 0.551 \\
\hline \multirow[t]{2}{*}{ Business Services (t-1) } & overall & 0.119 & 0.025 & 0.072 & 0.23 \\
\hline & within & & 0.005 & 0.103 & 0.132 \\
\hline \multirow[t]{2}{*}{ Pat_ISS (t-1) } & overall & 0.130 & 0.073 & 0 & 0.623 \\
\hline & within & & 0.033 & -0.028 & 0.532 \\
\hline \multirow[t]{2}{*}{ ISS (t-1) } & overall & 0.222 & 0.094 & 0.06 & 0.442 \\
\hline & within & & 0.008 & 0.186 & 0.250 \\
\hline \multirow[t]{2}{*}{ Students (t-1) } & overall & 1.641 & 3.695 & 0 & 30.038 \\
\hline & within & & 0.894 & -5.079 & 8.111 \\
\hline \multirow[t]{2}{*}{ Publications (t-2) } & overall & 0.646 & 2.169 & 0 & 18.317 \\
\hline & within & & 0.463 & -2.601 & 8.184 \\
\hline \multirow[t]{2}{*}{ IPRs (t-4) } & overall & 0.004 & 0.014 & 0 & 0.167 \\
\hline & within & & 0.011 & -0.035 & 0.143 \\
\hline
\end{tabular}

Summary statistics calculated for 594 observations: 99 provinces observed for 6 years $(\mathrm{T}=6)$. 


\section{Table 2: Correlation Matrix}

\begin{tabular}{|c|c|c|c|c|c|c|c|c|c|c|c|c|c|c|c|c|}
\hline Variables & 1 & 2 & 3 & & 4 & 5 & 6 & 7 & 8 & 9 & 10 & 11 & 12 & 13 & 14 & 15 \\
\hline 1d_vaindss & 1 & & & & & & & & & & & & & & & \\
\hline $2 d_{-}$va & 0.38 & 1 & & & & & & & & & & & & & & \\
\hline 3Log_VAPC & -0.061 & -0.128 & 1 & & & & & & & & & & & & & \\
\hline 4d_vaindss (t-1) & 0.114 & 0.229 & -0.126 & 1 & & & & & & & & & & & & \\
\hline 5d_va_lag (t-1) & 0.079 & 0.158 & -0.092 & 0.437 & 1 & & & & & & & & & & & \\
\hline 6Manu_E & 0.096 & 0.135 & -0.498 & 0.082 & 0.049 & & 1 & & & & & & & & & \\
\hline $7 \mathrm{E}$ & 0 & 0.141 & -0.313 & 0.028 & 0.07 & & 0.673 & 1 & & & & & & & & \\
\hline 8High_Share & -0.061 & 0.028 & 0.502 & 0.016 & 0.064 & & -0.336 & -0.184 & 1 & & & & & & & \\
\hline 9Ki_Share & -0.025 & -0.066 & 0.028 & -0.063 & -0.042 & & -0.047 & -0.049 & 0.007 & 1 & & & & & & \\
\hline 10Business Services & -0.079 & -0.106 & 0.369 & -0.108 & -0.055 & & -0.167 & -0.033 & 0.245 & 0.041 & 1 & & & & & \\
\hline 11Pat_ISS & 0.013 & -0.022 & 0.373 & -0.046 & -0.034 & & -0.181 & -0.184 & 0.303 & -0.012 & 0.374 & 1 & & & & \\
\hline 12ISS & -0.122 & -0.035 & 0.326 & -0.038 & -0.018 & & -0.572 & -0.108 & 0.251 & -0.006 & 0.047 & 0.14 & 1 & & & \\
\hline 13Studentss & -0.024 & -0.098 & 0.154 & -0.035 & -0.08 & & -0.089 & -0.007 & 0.116 & 0.02 & 0.404 & 0.137 & 0.057 & 1 & & \\
\hline 14Publications & -0.032 & 0.027 & 0.124 & 0.01 & 0.043 & & -0.078 & -0.075 & 0.068 & 0.015 & 0.181 & 0.184 & 0.031 & -0.079 & 1 & \\
\hline 15IPRs & -0.018 & 0.025 & -0.104 & -0.018 & -0.008 & & 0.11 & 0.047 & -0.068 & 0.047 & -0.017 & -0.003 & -0.035 & -0.025 & 0.049 & 1 \\
\hline
\end{tabular}




\section{$4 \quad$ Results}

Table 3 shows the spatial dependence of the variables, both in their original form and 'within' (taken into deviation of the province mean over time). We report the Moran's I test (Moran, 1950) to measure spatial dependence, which is calculated as follows:

$$
\text { Moran's I }=(\mathrm{x}-\mu)^{\prime} \mathrm{W}(\mathrm{x}-\mu) /(\mathrm{x}-\mu)^{\prime}(\mathrm{x}-\mu)
$$

where $x$ is the column vector of the variable of interest, $\mu$ is the mean of $x$ and $W$ is the weighting matrix. The first columns of the table shows the cross-sectional dependences of the original variables, whereas the later columns present the same for the 'within's. The Moran's I test suggests the existence of spatial dependence in the case of value added growth in the Manufacturing sector. A log-likelihood test on LSDV (fixed effects) against the pooled OLS indicates the existence of province-specific fixed effects. Hence, we will only report the estimations for FE-W (Fixed Effects - Within) and the SEM and SAR transformations.

Table 3: Test of Spatial Dependence

\begin{tabular}{lrrrr}
\hline & \multicolumn{2}{c}{ Original } & \multicolumn{2}{c}{ Within } \\
\hline Variables & Moran I & p-value & Moran I & p-value \\
\hline d_vaindss & -0.031 & 0.14 & -0.05 & 0.035 \\
d_va & 0.004 & 0.42 & -0.009 & 0.399 \\
Log_VAPC & -0.013 & 0.339 & 0.027 & 0.138 \\
d_vaindss (t-1) & 0.07 & 0.004 & 0.058 & 0.013 \\
d_va_lag (t-1) & 0.024 & 0.169 & 0.022 & 0.185 \\
Manu_E & 0.038 & 0.066 & 0.008 & 0.36 \\
E & 0.038 & 0.065 & -0.013 & 0.34 \\
High_Share & 0.036 & 0.08 & -0.013 & 0.335 \\
Ki_Share & 0.014 & 0.276 & -0.015 & 0.315 \\
Business Services & 0.097 & 0 & 0.03 & 0.121 \\
Pat_ISS & 0.04 & 0.058 & -0.054 & 0.021 \\
ISS & 0.086 & 0.001 & 0.002 & 0.446 \\
Studs & 0.167 & 0 & 0.065 & 0.005 \\
Pubs & 0.066 & 0.004 & 0.004 & 0.404 \\
IPRs & -0.004 & 0.459 & -0.007 & 0.424 \\
\hline
\end{tabular}

We do not observe spatial dependence in the case of value added growth across all sectors. This result may not be surprising for two reasons. Firstly, the service sector covers almost three quarters of the Italian GDP (ISTAT, 2009) and services tend to serve local markets. 
Secondly, the spatial peculiarity of Italian provinces (with the dominant capital city), minimizes the existence of inter-provincial productivity gains.

Table 4 reports the results from the fixed effect estimations of the growth equations in the restricted industry sector (Equations (1)-(3)). Table 5 reports the fixed effect estimation outputs of the growth equations for the whole economy. The first part of both tables illustrates the estimates for the basic model; the right side of the table adds the interactions of the measures of academic activities with business entry. The models for economic growth in the restricted industry have weaker explanatory power than the models for total economic growth. The regressions for value added growth across all sectors show a better goodness of fit (Rsquared around 58\%) versus that for value added growth in the restricted industry (R-squared around 23\%). As expected, the growth rate of value added in the restricted industry shows significant spatial interdependencies. Furthermore, a log-likelihood test indicates a higher explanatory power of SAR as compared to SEM at the $10 \%$ confidence level. Finally, a LR test rejects the existence of spatial dependence in Table 5. Although we present all estimations for the sake of completeness, we will only discuss the findings of the FE-W SAR for the value added growth in the restricted industry (Table 4) and the estimates of the FE-W for the growth in value added for all sectors (Table 5).

\subsection{Economic Growth in the Restricted Industry Sector}

The results in table 4 indicate that productivity gains have spatial interdependencies in the context of the restricted industry. The coefficients associated with the spatially lagged dependent variables and spatial error component are both significant, as expected from the Moran's I test in table 3. The measures of new business formations have a negative effect on the growth of value added. In the first place, business entry shows negative effects on the rate of growth of value added, although nonsignificant. Furthermore, the share of new businesses in the high-tech sector is negatively and significantly correlated with our growth measure. These findings contradict the existing evidence on the direct effects of entry on economic growth in the short-run (Fritsch and Mueller, 2008), which predicts an immediate positive impact of entry on economic growth. The results can have two interpretations. Firstly, entry in the restricted industry in Italian provinces might be mainly driven by necessity, rather than opportunity. This interpretation is barely plausible as necessity entrepreneurship is mainly observable through lower exit rates (Santarelli et al, 2009). Secondly, the indirect effects of 
entry might prevail over the direct ones. New ventures push inefficient existing capacities out of the market and are responsible for market turbulence. This explanation seems to be the most reasonable as high shares of high-tech ventures may be responsible for a process of sectoral transformation. ${ }^{9}$

The presence of universities can per se have beneficial implications for the rate of growth in value added in the restricted industry. The presence of graduates is positively correlated with value added growth in the restricted industry, significantly at the $10 \%$ confidence level. The provision of graduates to the labour market is not only beneficial for the competitiveness of the local manufacturing base, but also for the adjacent provinces. The coefficients related to the scientific production and commercial orientation of research are all nonsignificant. Given the specialization in traditional sectors of the Italian manufacturing sector, the absent contribution of scientific and technological outputs to value added growth does not come as surprise. Moreover, at least in the case of Italian provinces, we do not observe any superior ability of new ventures to exploit commercially the knowledge produced in universities, irrespective of the efforts the latter take to facilitate the transfer of it. The set of controls sheds some light on the process of structural change occurring in Italy. Provinces with a strong presence of manufacturing activities witness lower growth rates in value added. The innovative intensity of the manufacturing industry in the province is positive and feebly insignificant, in line with an industrial base formed by mostly small firms in sectors with low propensity to patent. Increases in the presence of business services activities are associated with decreases in the growth of value added in the restricted industry. Ceteris paribus, the growth rate in the restricted industry is more accentuated in richer provinces, mostly located in the Centre-North, with the coefficient for value added per capita being positive and significant.

\footnotetext{
9 Quatraro (2009) details the process of structural change that occurred in Italian regions between 1980 and 2000. The author documents a process of de-industrialization in the early-industrialized Northwest regions with consequent transformation to a knowledge-based economy, and an increasing specialization in manufacturing activities in the Northeast and Central regions focused on traditional sectors. Furthermore the author shows that a process of recent industrialization is occurring in the developing South.
} 
Table 4: Growth in value added (restricted industry).

\begin{tabular}{|c|c|c|c|c|c|c|}
\hline & FE-W & FE-W SEM & FE-W SAR & FE-W & FE-W SEM & FE-W SAR \\
\hline Log_VAPC(t-1) & $\begin{array}{r}0.3448 * * * \\
(0.1026)\end{array}$ & $\begin{array}{r}0.3438 * * * \\
(0.0961)\end{array}$ & $\begin{array}{r}0.3353 * * * \\
(0.0964)\end{array}$ & $\begin{array}{r}0.3561 * * * \\
(0.1026)\end{array}$ & $\begin{array}{r}0.3567 * * * \\
(0.0973)\end{array}$ & $\begin{array}{r}0.3473 * * * \\
(0.0976)\end{array}$ \\
\hline d_va (t-1) & $\begin{array}{r}-0.0717 \\
(0.0467)\end{array}$ & $\begin{array}{c}-0.0610 * \\
(0.0358)\end{array}$ & $\begin{array}{c}-0.0679 * \\
(0.0356)\end{array}$ & $\begin{array}{l}-0.0711 \\
(0.0466)\end{array}$ & $\begin{array}{c}-0.0599 * \\
(0.0357)\end{array}$ & $\begin{array}{c}-0.0671 * \\
(0.0356)\end{array}$ \\
\hline Manu_E(t) & $\begin{array}{l}-0.0019 \\
(0.0015)\end{array}$ & $\begin{array}{l}-0.0012 \\
(0.0013)\end{array}$ & $\begin{array}{l}-0.0014 \\
(0.0012)\end{array}$ & $\begin{array}{l}-0.0015 \\
(0.0015)\end{array}$ & $\begin{array}{l}-0.0007 \\
(0.0014)\end{array}$ & $\begin{array}{r}-0.001 \\
(0.0013)\end{array}$ \\
\hline High_Share(t) & $\begin{array}{r}-0.1047 \\
(0.0686)\end{array}$ & $\begin{array}{r}-0.1161 * * \\
(0.0592)\end{array}$ & $\begin{array}{l}-0.1122 * \\
(0.0588)\end{array}$ & $\begin{array}{r}-0.1014 \\
(0.0691)\end{array}$ & $\begin{array}{l}-0.1127^{*} \\
(0.0592)\end{array}$ & $\begin{array}{c}-0.1087 * \\
(0.0588)\end{array}$ \\
\hline Business Services (t-1) & $\begin{array}{r}-1.4364 * * \\
(0.6273)\end{array}$ & $\begin{array}{r}-1.3742 * * * \\
(0.526)\end{array}$ & $\begin{array}{r}-1.4116^{* * * *} \\
(0.525)\end{array}$ & $\begin{array}{r}-1.4453 * * \\
(0.6225)\end{array}$ & $\begin{array}{r}-1.3916 * * * \\
(0.5332)\end{array}$ & $\begin{array}{r}-1.4183 * * * \\
(0.5321)\end{array}$ \\
\hline Pat_ISS (t-1) & $\begin{array}{l}0.0722 * \\
(0.0434)\end{array}$ & $\begin{array}{l}0.0789 * \\
(0.0479)\end{array}$ & $\begin{array}{r}0.0757 \\
(0.0472)\end{array}$ & $\begin{array}{r}0.0708 \\
(0.0432)\end{array}$ & $\begin{array}{r}0.0771 \\
(0.0479)\end{array}$ & $\begin{array}{r}0.0742 \\
(0.0472)\end{array}$ \\
\hline ISS $(t-1)$ & $\begin{array}{r}-1.6678 * * * \\
(0.2927)\end{array}$ & $\begin{array}{r}-1.6255 * * * \\
(0.2466)\end{array}$ & $\begin{array}{r}-1.6377 * * * \\
(0.2457)\end{array}$ & $\begin{array}{r}-1.6673 * * * \\
(0.2907)\end{array}$ & $\begin{array}{r}-1.6232 * * * \\
(0.2471)\end{array}$ & $\begin{array}{r}-1.6363 * * * \\
(0.2461)\end{array}$ \\
\hline Students (t-1) & $\begin{array}{r}0.0034 \\
(0.0025)\end{array}$ & $\begin{array}{r}0.0035^{*} \\
(0.002)\end{array}$ & $\begin{array}{r}0.0034^{*} \\
(0.002)\end{array}$ & $\begin{array}{l}0.0049 \\
(0.004)\end{array}$ & $\begin{array}{l}0.0052 * \\
(0.0029)\end{array}$ & $\begin{array}{l}0.0051^{*} \\
(0.0029)\end{array}$ \\
\hline Publications (t-1) & $\begin{array}{r}0.0022 \\
(0.0026)\end{array}$ & $\begin{array}{r}0.0007 \\
(0.0035)\end{array}$ & $\begin{array}{r}0.0009 \\
(0.0035)\end{array}$ & $\begin{array}{l}0.0042 \\
(0.007)\end{array}$ & $\begin{array}{r}0.003 \\
(0.0073)\end{array}$ & $\begin{array}{r}0.0031 \\
(0.0073)\end{array}$ \\
\hline IPRs (t-4) & $\begin{array}{l}-0.1781 \\
(0.1186)\end{array}$ & $\begin{array}{l}-0.1997 \\
(0.1457)\end{array}$ & $\begin{array}{r}-0.1996 \\
(0.1452)\end{array}$ & $\begin{array}{r}-0.063 \\
(0.2571)\end{array}$ & $\begin{array}{r}-0.0446 \\
(0.3098)\end{array}$ & $\begin{array}{r}-0.0847 \\
(0.3088)\end{array}$ \\
\hline Students*E & & & & $\begin{array}{l}-0.3274 \\
(0.4051)\end{array}$ & $\begin{array}{r}-0.3579 \\
(0.456)\end{array}$ & $\begin{array}{r}-0.357 \\
(0.4498)\end{array}$ \\
\hline Publications* ${ }^{*}$ & & & & $\begin{array}{r}-0.0003 \\
(0.0011)\end{array}$ & $\begin{array}{r}-0.0004 \\
(0.001)\end{array}$ & $\begin{array}{r}-0.0003 \\
(0.001)\end{array}$ \\
\hline IPRs*E & & & & $\begin{array}{r}-0.0088 \\
(0.021)\end{array}$ & $\begin{array}{r}-0.0123 \\
(0.0243)\end{array}$ & $\begin{array}{r}-0.0087 \\
(0.0242)\end{array}$ \\
\hline Spatial Residuals & & $\begin{array}{c}-0.0380 * \\
(0.0211)\end{array}$ & & & $\begin{array}{c}-0.0399 * \\
(0.0212)\end{array}$ & \\
\hline Spatial Growth & & & $\begin{array}{r}-0.0456 * * \\
(0.0178)\end{array}$ & & & $\begin{array}{r}0.0461 * * * \\
(0.0178)\end{array}$ \\
\hline R-squared & 0.2298 & & & 0.2309 & & \\
\hline Log-Likelihood & $1,097.608$ & $1,099.242$ & $1,100.891$ & $1,098.031$ & $1,098.809$ & $1,101.381$ \\
\hline $\mathrm{N}$ & 594 & 594 & 594 & 594 & 594 & 594 \\
\hline
\end{tabular}

Significance at the $1 \%, 5 \%$, and $10 \%$ level is indicated by ***, **, and *, respectively. Standard errors, reported below coefficients, are robust to heteroskedasticity and clustered around provinces. Year dummies are included in each model. 


\subsection{Overall Economic Growth}

Table 5 reports the results for the total growth rate of value added at the provincial level. We will mention here only the differences with the estimates found for the restricted industry.

Table 5: Growth in value added (all sectors).

\begin{tabular}{|c|c|c|c|c|c|c|}
\hline & FE-W & FE-W SEM & FE-W SAR & FE-W & FE-W SEM & FE-W SAR \\
\hline Log_VAPC(t-1) & $\begin{array}{r}0.2903 * * * \\
(0.0581)\end{array}$ & $\begin{array}{r}0.2860^{* * * *} \\
(0.0475)\end{array}$ & $\begin{array}{r}0.2861 * * * \\
(0.0477)\end{array}$ & $\begin{array}{r}0.2869 * * * \\
(0.0584)\end{array}$ & $\begin{array}{r}0.2824 * * * \\
(0.0476)\end{array}$ & $\begin{array}{r}0.2833 * * * \\
(0.0477)\end{array}$ \\
\hline d_va (t-1) & $\begin{array}{r}-0.1669 * * * \\
(0.0383)\end{array}$ & $\begin{array}{r}-0.1645 * * * \\
(0.0367)\end{array}$ & $\begin{array}{r}-0.1638 * * * \\
(0.0372)\end{array}$ & $\begin{array}{r}-0.1789 * * * \\
(0.0394)\end{array}$ & $\begin{array}{r}-0.1762 * * * \\
(0.0367)\end{array}$ & $\begin{array}{r}-0.1757 * * * \\
(0.0372)\end{array}$ \\
\hline $\mathrm{E}(\mathrm{t})$ & $\begin{array}{r}-0.0011 \\
(0.001)\end{array}$ & $\begin{array}{l}-0.001 \\
(0.001)\end{array}$ & $\begin{array}{l}-0.001 \\
(0.001)\end{array}$ & $\begin{array}{c}-0.0020^{*} \\
(0.0011)\end{array}$ & $\begin{array}{c}-0.0019 * \\
(0.0011)\end{array}$ & $\begin{array}{c}-0.0019^{*} \\
(0.0011)\end{array}$ \\
\hline Ki_Share(t) & $\begin{array}{r}-0.0033 \\
(0.0148)\end{array}$ & $\begin{array}{c}-0.0062 \\
(0.0132)\end{array}$ & $\begin{array}{r}-0.0042 \\
(0.013)\end{array}$ & $\begin{array}{r}-0.0031 \\
(0.0147)\end{array}$ & $\begin{array}{r}-0.0058 \\
(0.0131)\end{array}$ & $\begin{array}{l}-0.0039 \\
(0.0129)\end{array}$ \\
\hline Business Services (t-1) & $\begin{array}{r}0.7206^{* *} \\
(0.3297)\end{array}$ & $\begin{array}{r}0.7685^{* * * *} \\
(0.2582)\end{array}$ & $\begin{array}{r}0.7240 * * * \\
(0.2564)\end{array}$ & $\begin{array}{r}0.8576 \text { ** } \\
(0.3316)\end{array}$ & $\begin{array}{r}0.9016 * * * \\
(0.2621)\end{array}$ & $\begin{array}{r}0.8588^{* * * *} \\
(0.2602)\end{array}$ \\
\hline Pat_ISS (t-1) & $\begin{array}{r}0.0197 \\
(0.0236)\end{array}$ & $\begin{array}{r}0.0146 \\
(0.0235)\end{array}$ & $\begin{array}{l}0.0191 \\
(0.023)\end{array}$ & $\begin{array}{r}0.02 \\
(0.0234)\end{array}$ & $\begin{array}{r}0.0151 \\
(0.0233)\end{array}$ & $\begin{array}{r}0.0194 \\
(0.0229)\end{array}$ \\
\hline ISS (t-1) & $\begin{array}{r}-0.0113 \\
(0.1504)\end{array}$ & $\begin{array}{r}0.0129 \\
(0.1171)\end{array}$ & $\begin{array}{r}-0.0074 \\
(0.1163)\end{array}$ & $\begin{array}{r}0.0127 \\
(0.1481)\end{array}$ & $\begin{array}{l}0.0377 \\
(0.117)\end{array}$ & $\begin{array}{r}0.0158 \\
(0.1159)\end{array}$ \\
\hline Students (t-1) & $\begin{array}{r}-0.002 * * \\
(0.001)\end{array}$ & $\begin{array}{r}-0.0019 * * \\
(0.001)\end{array}$ & $\begin{array}{r}-0.002 * * \\
(0.001)\end{array}$ & $\begin{array}{r}-0.0028 * * * \\
(0.0011)\end{array}$ & $\begin{array}{r}-0.0028 \\
(0.0017)\end{array}$ & $\begin{array}{l}-0.0027 \\
(0.0017)\end{array}$ \\
\hline Publications (t-1) & $\begin{array}{r}0.0032 * * * \\
(0.0006)\end{array}$ & $\begin{array}{l}0.0030^{*} \\
(0.0017)\end{array}$ & $\begin{array}{c}0.0029 * \\
(0.0017)\end{array}$ & $\begin{array}{r}-0.0043 \\
(0.0042)\end{array}$ & $\begin{array}{r}-0.0048 \\
(0.0062)\end{array}$ & $\begin{array}{l}-0.0045 \\
(0.0062)\end{array}$ \\
\hline IPRs (t-4) & $\begin{array}{r}-0.0914 \\
(0.0666)\end{array}$ & $\begin{array}{l}-0.0921 \\
(0.0696)\end{array}$ & $\begin{array}{r}-0.0926 \\
(0.0696)\end{array}$ & $\begin{array}{r}-0.8640 * * * \\
(0.3131)\end{array}$ & $\begin{array}{r}-0.8377 * * \\
(0.326)\end{array}$ & $\begin{array}{r}-0.8496 * * * \\
(0.3255)\end{array}$ \\
\hline Students*E & & & & $\begin{array}{r}0.1107 \\
(0.1626)\end{array}$ & $\begin{array}{r}0.1257 \\
(0.2275)\end{array}$ & $\begin{array}{r}0.0995 \\
(0.2259)\end{array}$ \\
\hline Publications*E & & & & $\begin{array}{l}0.0008^{*} \\
(0.0005)\end{array}$ & $\begin{array}{r}0.0009 \\
(0.0007)\end{array}$ & $\begin{array}{r}0.0008 \\
(0.0007)\end{array}$ \\
\hline IPRs*E & & & & $\begin{array}{r}0.0815 * * \\
(0.0353)\end{array}$ & $\begin{array}{r}0.0785 * * \\
(0.0337)\end{array}$ & $\begin{array}{r}0.0799^{* *} \\
(0.0337)\end{array}$ \\
\hline Spatial Residuals & & $\begin{array}{r}-0.0307 \\
(0.0206)\end{array}$ & & & $\begin{array}{r}-0.0294 \\
(0.0208)\end{array}$ & \\
\hline Spatial Growth & & & $\begin{array}{r}-0.0197 \\
(0.0125) \\
\end{array}$ & & & $\begin{array}{r}-0.0184 \\
(0.0124) \\
\end{array}$ \\
\hline R-squared & 0.5853 & & & 0.5887 & & \\
\hline Log-Likelihood & $1,526.719$ & $1,527.824$ & $1,527.96$ & $1,530.732$ & $1,531.733$ & $1,531.817$ \\
\hline $\mathrm{N}$ & 594 & 594 & 594 & 594 & 594 & 594 \\
\hline
\end{tabular}

Significance at the $1 \%, 5 \%$, and $10 \%$ level is indicated by $* * *, * *$, and $*$, respectively. Standard errors, reported below coefficients, are robust to heteroskedasticity and clustered around provinces. Year dummies are included in each model. 
Entry in manufacturing and services at first does not show any significant impact on economic growth. Yet, contrary to what we observed for the restricted industry, it turns significant with positive implications for growth when it is interacted with measures of academic outputs. There is not any sign of growth premia from entry in knowledge-intensive sectors, the latter being still in a process of consolidation in large parts of the country (Quatraro, 2009). Large increases in the fractions of graduates in science and technology disciplines are associated with decreases in the growth rate of value added. Two possible reasons can account for this finding. The first reason is that rather than capturing the presence of human capital in the local economy, which has possible implications from the supply side of the economy, our measure of educational mandate of universities highlights the consequences accruing from the demand side: large fractions of graduates indicate large presences of students, with low spending power. The second reason is that the increases in the number of graduates reflect recent changes in education policies that followed the implementation of the so-called Bologna Process. Universities have decentralized part of their teaching activities in provinces with poor economic performances to meet the local demand for higher education. Yet, the economic results of this delocalization policy have proven to be rather unsatisfactory (Piergiovanni et al., 2011). If the output of teaching activities is controversial in terms of economic performance, the coefficient for the production of scientific knowledge is positive and significant. Consistent with Piergiovanni et al. (2011), this finding shows that more than just the presence of academic institutions in the province, what really matters in relation to economic growth is their relative quality.

Involvement of universities in IPR management activities does not show any effect on the rate of growth in value added. The interaction between entry and the outputs of academic activities confirms the positive impact of sustained entrepreneurial regimes for the economic exploitation of scientific knowledge in its traditional form. The effect is significant for provinces hosting universities at the forefront in the production of scientific knowledge. On the opposite, entrepreneurial attitudes of universities, that we measure in terms of their involvement in IPRs management activities, are beneficial for economic growth when they are accompanied by a business climate that encourage the creation of new ventures in the private sector. This result can well be explained by the fact that in Italy, like in most other European countries, universities have little control on the commercial activities of their 
faculties, who usually leave exclusive ownership of their inventions to business parties, typically large firms (Della Malva et al., 2007). Thus, policies that institutionalize the commercial exploitation of academic technologies appear to reduce the costs of access to university labs to newly formed ventures. Patenting, which was found to significantly accelerate value added growth in restricted industry, does not affect total value added growth in the provinces. On the contrary, the growth in the workforce in the business services sector has a positive and significant influence on the rate of growth of value added. The two outcomes are mainly explained by the decreasing relevance of manufacturing activities as the tertiary sector, which does not make use of patents, represents the largest share of the whole economy (ISTAT, 2009). Provinces with higher than average value added per capita, mostly located in the more developed North and Center of the country, grow at a faster rate. This result indicates that the economic divide between the developed areas of the country and the South has increased during the period of analysis.

\section{Concluding Remarks}

In the transformation to a knowledge based economy, universities stand as key players as they are a vital locus of knowledge production. Yet, for knowledge to contribute to economic growth, it needs to spill from academic institutions over to the economy in the form of new entrepreneurial ventures. By using spatial econometric techniques, this work has tested the hypothesis that new business entrants are critical in the economic exploitation of academic knowledge and its contribution to economic growth. This hypothesis has been derived from the theoretical framework proposed by Acs et al. (2009) and Braunerhjelm et al. (2010), which extend traditional models of endogenous growth by accounting for knowledge transmission channels. According to the authors, new business entrants are critical conduits of radical knowledge, like academic knowledge, into economic outcomes as they face lower opportunity costs than incumbent firms when confronted with radical opportunities.

We have measured the contribution of three main outputs of academic mandates, namely teaching, research and technological development, to the rate of growth in value added for 99 Italian provinces between 2001 and 2006, both in the restricted industry and across all sectors. Controlling for several characteristics of the economic structure of the provinces, we have found that scientific knowledge, only in the form of newly educated 
workforce, yields significant effects on the growth rate of value added in the restricted industry. The effects of academic outputs are appreciable across all sectors when they are associated with sustained entrepreneurial activities in the province. In particular, the traditional mandate of scientific inquiry seems to provide new ventures with valuable commercial opportunities overseen by established companies: as new companies are not constrained by existing productive architectures, entrepreneurs are more likely to identify and exploit opportunities. Furthermore, entrepreneurial policies which favor the Industry-Science links appear to be effective for the economic exploitation of academic knowledge by new ventures: when risk-taking endeavours are pursued by both the private and the public actors, then scientific knowledge can generate positive economic externalities. However, these findings fail to hold when we limit our analysis to value added growth in the restricted industry, for which the presence of high entry rates as such turns out to be detrimental.

To conclude, our findings suggest that neither entrepreneurship as such nor academic knowledge alone contribute to sustained economic growth in the case of Italian provinces. It is only when entrepreneurship is combined with access to scientific knowledge and universities are prone to collaborate with external parties that their ventures may significantly stimulate growth. Thereby, new ventures appear to be effective conduits of scientific knowledge into economic outcomes.

\section{References}

Acs, Z. J., Braunerhjelm, P., Audretsch, D. B., \& Carlsson, B. (2009). "The Knowledge Spillover Theory of Entrepreneurship", Small Business Economics, 32(1): 15-30.

Adams, J. D. (1990). "Fundamental Stocks of Knowledge and Productivity Growth", Journal of Political Economy, 98(4): 673-702.

Agarwal, A., \& Henderson, R. (2002). "Putting Patents in Context: Exploring Knowledge Transfer from MIT", Management Science, 48(1): 44-60.

Agarwal, R., Echambadi, R. , Franco, A.. \& Sarkar, M. B. (2004), "Knowledge Transfer through Inheritance: Spin-out Generation, Growth and Survival", Academy of Management Journal, 47(4): 501-522.

Anselin, L. (1988). Spatial Econometrics: Methods and Models, Dordrecht: Kluwer.

Arora, A., \& Gambardella, A. (1994). "The Changing Technology of Technological Change: General and Abstract Knowledge and the Division of Innovative Labour", Research Policy, 23(5): 523-532. 
Arrow, K. (1962). "Economic Welfare and the Allocation of Resources for Innovation", in R. R. Nelson (editor), The Rate and Direction of Inventive Activity, Cambridge (MA): NBER Books, 609-626.

Audretsch, D. B. (1995). Innovation and Industry Evolution, Cambridge (MA): MIT Press.

Audretsch, D. B. (2007). "Entrepreneurship Capital and Economic Growth", Oxford Review of Economic Policy, 93(1): 63-78.

Audretsch, D. B., \& Keilbach, M. (2008). "Resolving the Knowledge Paradox: Knowledgespillover Entrepreneurship and Economic Growth", Research Policy, 37(10): 16971705.

Audretsch, D. B., \& Lehmann, E. E. (2005), "Does the Knowledge Spillover Theory of Entrepreneurship Hold for Regions?", Research Policy, 34(8): 1191-1202.

Azoulay, P., Ding, W., \& Stuart, T. (2009). "The Effect of Academic Patenting on the Rate, Quality, and Direction of (Public) Research Output", Journal of Industrial Economics, 57(4): 637-676.

Bania, N., Eberts, R. W., \& Fogarty, M. S. (1993). "Universities and the Startup of New Companies: Can We Generalize from Route 128 and Silicon Valley?", Review of Economics and Statistics, 75(4): 761-66.

Barro, R. J. (1991). "Economic Growth in a Cross Section of Countries", Quarterly Journal of Economics, 106(2): 407-443.

Baumol, W. J., Panzar, J. C., \& Willig, R. D. (1988). Contestable Markets and the Theory of Industry Structure, San Diego: Harcourt Brace Jovanovic.

Becker, G. (1964). Human Capital: A Theoretical and Empirical Analysis, with Special Reference to Education, New York: Columbia University Press.

Braunerhjelm, P., Acs, Z. J., Audretsch, D. B., \& Carlsson, B. (2010). “The Missing Link: The Knowledge Filter and Entrepreneurship in Endogenous Growth", Small Business Economics, 34(2): 105-125.

Breznitz, S.M. (2011), "Improving or Impairing? Following Technology Transfer Changes at the University of Cambridge”, Regional Studies, 45(4): 463-478.

Buensdorf, G., \& Klepper, S. (2009). "Heritage and Agglomeration: The Akron Tyre Cluster Revisited", Economic Journal, 119(537): 705-733.

Bun, M. J. G., \& Carree, M. A. (2005). "Bias-corrected estimation in dynamic panel data models", Journal of Business \& Economic Statistics, 23(2): 200-210.

Christensen, C. M. (1997). The Innovator's Dilemma: When New Technologies Cause Great Firms to Fail, Boston: Harvard Business School Press.

Cohen, W. M., \& Levinthal, D. A. (1990). “Absorptive Capacity: A New Perspective on Learning and Innovation", Administrative Science Quarterly, 35(1): 128-152.

Colyvas, J., M., Crow, A., Gelijns, R., Mazzoleni, R., Nelson, R. R., Rosenberg, N., \& Sampat, B. N. (2002). "How Do University Inventions Get Into Practice?", Management Science, 48(1): 61-72.

Czarnitzki, D., Hussinger, K., \& Schneider, C. (forthcoming). "The Nexus Between Science and Industry: Evidence From Faculty Inventions", Journal of Technology Transfer. 
Dasgupta, P., \& David, P. (1994). “Toward a New Economics of Science”, Research Policy, 23(5): 487-521.

Della Malva A., Breschi S., Lissoni F. \& Montobbio F. (2007) "L'Attività Brevettuale dei Docenti Universitari: l'Italia in un Confronto Internazionale", Economia e Politica Industriale, 34(2): 43-70.

Elhorst, P. J. (2003). "Specification and Estimation of Spatial Panel Data Models", International Regional Science Review, 26(3): 244-268.

Europe Innova (2010), Priority Sector Report: Creative and Cultural Industries, Deliverable D9-1, Brussels: European Commission.

Feldman, M. P., \& Desrochers, P. (2003). "Research Universities and Local Economic Development: Lessons from the History of Johns Hopkins University”, Industry and Innovation, 10(1): 5-24.

Fini, R., Grimaldi, R., \& Sobrero, M. (2009). "Factors Fostering Academics to Start Up New Ventures: An Assessment of Italian Founders' Incentives", Journal of Technology Transfer, 34(4): 380-402.

Fleming, L., \& Sorenson, O. (2004). "Science as a Map in Technological Search", Strategic Management Journal, 25(8-9): 909-928.

Franzoni, C. (2009). "Do Scientists get Fundamental Research Ideas by Solving Practical Poblems?", Industrial and Corporate Change, 18(4): 671-699.

Fritsch, M., \& Mueller, P. (2008). "The Effect of New Business Formation on Regional Development Over Time: The Case of Germany", Small Business Economics, 30(1): 15-29.

Geroski P., \& Jacquemin, A. (1984). "Dominant Firms and their Alleged Decline", International Journal of Industrial Organization, 2(1): 1-27.

Glaeser, E. L., \& Kerr, W. R. (2009). "Local Industrial Conditiond and Entrepreneurship: How Much of the Spatial Distribution Can We Explain?", Journal of Economics \& Management Strategy, 18(3): 623-663.

Hayter, C.S. (2011), "In Search of the Profit-maximizing Actor: Motivations and Definitions of Success from Nascent Academic Entrepreneurs", Journal of Technology Transfer 36(3): 340-352.

Jensen, R. A. \& Thursby, M. C. (2001). "Proofs and Prototypes for Sale: The Licensing of University Inventions", American Economic Review, 91(1): 240-259.

Jensen, R. A., Thursby, J. G., \& Thursby, M. C. (2003). "Disclosure and Licensing of University Inventions: 'The Best We Can Do with the $\mathrm{S}^{* * t}$ We Get To Work with"', International Journal of Industrial Organization, 21(9): 1271-1300.

Henderson, R., Jaffe, A. B., \& Trajtenberg, M. (1998). "Universities as a Source of Commercial Technology: A Detailed Analysis of University Patenting 1965-88", The Review of Economics and Statistics, 80(1): 119-132.

Hill, C. W. L., \& Rothaermel, F. T. (2003). "The Performance of Incumbent Firms in the Face of Radical Technological Innovation", Academy of Management Review, 28 (2): 257274. 
ISTAT (2009). Conti Economici Trimestrali, retrieved from: http://www.istat.it/salastampa/comunicati/in_calendario/contitri/20091210_00/testoint egrale20091210.pdf

Klepper, S., \& Sleeper, S. (2005). "Entry by Spinoffs", Management Science, 51(8): 12911306.

Lissoni, F., Llerena, , McKelvey, P. M., \& Sanditov, B. (2008). "Academic Patenting in Europe: New Evidence from the KEINS Database", Research Evaluation, 17(2): 87102.

Lucas, R. E. (1988). "On the Mechanics of Economic Development", Journal of Monetary Economics, 22(1): 3-42.

Merton, R. K. (1973). The Sociology of Science: Theoretical and Empirical Investigations, Chicago: University of Chicago Press.

Moran, P. A. P. (1950). "Notes on Continuous Stochastic Phenomena", Biometrika, 37(1): $17-33$.

Mueller, P. (2006), "Exploring the Knowledge Filter: How Entrepreneurship and UniversityIndustry Relationships Drive Economic Growth", Research Policy 35(10): 1499-1508.

Mueller, P. (2007), "Exploiting Entrepreneurial Opportunities: The Impact of Entrepreneurship on Growth", Small Business Economics 28(4): 355-362.

Murmann, J. P. (2003). Knowledge and Competitive Advantage: The Coevolution of Firms, Technology and National Institutions, Boston: Cambridge University Press.

Nelson, R. R., \& Wright, G. (1992). "The Rise and Fall of American Technological Leadership: The Postwar Era in Historical Perspective", Journal of Economic Literature, 30(4): 1931-1964.

Owen-Smith, J., \& Powell, W. W. (2001). “To Patent or Not: Faculty Decisions and Institutional Success at Technology Transfer", Journal of Technology Transfer, 26(1): 99-114.

Patel, P., Arundel, A., \& Hopkins, M. (2008). Sectoral Innovation Systems in Europe: Monitoring, Analysing Trends and Identifying Challenges in Biotechnology, Brussels: Europe Innova, Sector Report.

Piergiovanni, R., \& Santarelli, E. (2001). "Patents and the Geographic Localization of R\&D Spillovers in French Manufacturing", Regional Studies, 35(8): 697-702.

Piergiovanni, R., Carree, M. A., \& Santarelli, E. (2011). "Creative Industries, New Business Formation, and Regional Economic Growth", Small Business Economics, forthcoming (DOI 10.1007/s11187-011-9329-4).

Pisano, G. (2006). Science Business: The Promise, the Reality and the Future of Biotech, Boston: Harvard Business School Press.

Prusa, T. J., \& Schmitz, J. A. (1991). "Are New Firms an Important Source of Innovation? Evidence from the PC Software Industry", Economic Letters, 35(3): 339-342.

Quatraro, F. (2009). "Innovation, Structural Change and Productivity Growth: Evidence from Italian Regions, 1980-2003”, Cambridge Journal of Economics, 33(5):1001-1022. 
Romer, P. M. (1986). “Increasing Returns and Long-run Growth", Journal of Political Economy, 94(5): 1002-1037.

Santarelli, E., Carree, M. A., \& Verheul, I. (2009). "Unemployment and Firm Entry and Exit: An Update on a Controversial Relationship”, Regional Studies, 43(8): 1061-1073.

Sampat B. N., Mowery, D. C., \& Ziedonis, A. A. (2003). "Changes in University Patent Quality After the Bayh-Dole Act: A Re-Examination", International Journal of Industrial Organization, 21(9): 1371-1390.

Saxenian, A. (1994). Regional Advantage: Culture and Competition in Silicon Valley and Route 128, Boston: Harvard University Press.

Shane, S. (2004). Academic Entrepreneurship: University Spinoffs and Wealth Creation, Aldershot: Edward Elgar.

Schumpeter, J. A. (1934). The Theory of Economic Development, New Brunswick (NJ): Transaction Publishers.

Spulber, D. F. (2010). "Competition Among Entrepreneurs", Industrial and Corporate Change, 19(1): 25-50.

Stephan, P. (1996). "The Economics of Science", Journal of Economic Literature, 34(3): 1199-1235.

Sterlacchini, A. (2008). "R\&D, Higher Education and Regional Growth: Uneven Linkages among European Regions", Research Policy, 37(6-7): 1096-1107.

Thurik, A. R., \& Carree, M. A. (2003). "The Impact of Entrepreneurship on Economic Growth", in Z. Acs and D. Audretsch (eds) Handbook of Entrepreneurship Research, Dordrecht: Kluwer Academic Publishers, Vol. 1, 437-471.

Zucker, L. G., Darby, M. R., \& Brewer, M. B. (1998a). "Intellectual Human Capital and the Birth of U.S. Biotechnology Enterprises", American Economic Review, 88(1): 290306.

Zucker, L. G., Darby, M. R., \& Armstrong, J. (1998b). "Geographically Localized Knowledge: Spillovers or Markets?”, Economic Inquiry, 36(1): 65-86. 


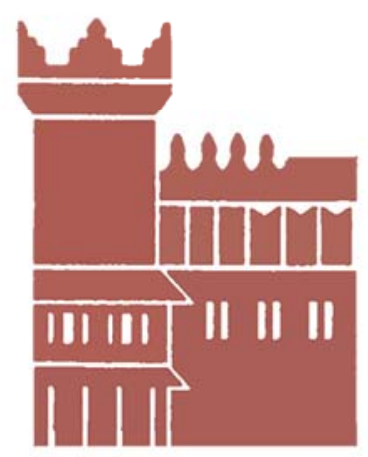

Alma Mater Studiorum - Università di Bologna DEPARTMENT OF ECONOMICS

Strada Maggiore 45

40125 Bologna - Italy

Tel. +39051 2092604

Fax +390512092664

http://www.dse.unibo.it 